Virtual Mentor. May 2003, Volume 5, Number 5.

doi: 10.1001/virtualmentor.2003.5.5.ccas3-0305

Clinical Cases

\title{
Just Don't Tell My Husband
}

\section{A physician must honor a patient's request to keep the information about her desire to have a tubal ligation from her husband, but the physician and patient should discuss the possible ramifications of concealing the procedure.}

Commentary by Carol Tauer, PhD, and Cynthia Daniels, PhD

Dr. Joe Wilkins delivered Carol Mason's first daughter 3 years ago, and her second daughter is due in 6 weeks. Mrs. Mason's pregnancy has been uncomplicated so far. At her last regular check-up a month ago, Mrs. Mason, who is now 33, asked whether Dr. Wilkins would "tie her tubes" at the time of the delivery. Dr. Wilkins agreed to do so.

At this visit, Mrs. Mason brings up the topic again and requests that Dr. Wilkins not tell her husband, John, about the tubal ligation. "I know he would like to have more children, and really wants a son," she explained.

"You're my patient, and there is no reason for me to tell your husband," Dr. Wilkins replies, "but you should think about the consequences of not telling him. He'll expect you to become pregnant again and wonder why you're not."

"I know, but I don't want any more children. I'm establishing a career that's important to me. John and I have had this conversation a dozen times, and it goes nowhere. The bottom line is, it's my body and I don't want any more children. But I just wanted to warn you that as soon as John sees you in delivery, he's going to ask how it went and whether it looks as though everything's all right for me to have more babies."

\section{Commentary 1}

by Carol Tauer, PhD

Carol Mason seems to be placing Dr. Wilkins in an untenable position. She wants him to perform a tubal ligation, conceal this procedure from her husband, and yet be prepared to respond to her husband's anticipated question: Is everything all right for my wife to have more babies?

Dr. Wilkins' first option is to refuse to perform the procedure. Two possible reasons would clearly justify such a refusal: if Dr. Wilkins had a moral objection to permanent sterilization, he would have every right to inform Mrs. Mason of that fact and refer her to another physician. Second, if the woman requesting the procedure were unable to give a true informed consent, either because she did not understand the nature of sterilization or because she was being coerced into having it, then Dr. Wilkins would not only be justified in refusing her, but he would be obligated to do so. There may be other situations in which a refusal would be legitimate, for example, a request for sterilization from a 19-year-old woman who has not had any children, but such cases are more debatable and require individual analysis.

At any rate, none of these possible justifications applies in the case of Mrs. Mason. Dr. Wilkins has already agreed to perform the procedure, and Mrs. Mason is simply making an additional request of him. How should he respond to her request? 
It is clear that Dr. Wilkins' patient in this case is Carol Mason, and that he owes her confidentiality with respect to her medical treatment. All medical codes of ethics stress the importance of confidentiality, and the HIPAA regulations that took effect on April 14 (2003) protect patient information under federal law. There is no spousal exception to the duty of confidentiality.

However, Dr. Wilkins needs to help Mrs. Mason consider the consequences of pursuing her plan to conceal her tubal ligation. She, as well as Dr. Wilkins, would likely be faced with years of questioning from her husband as to why she isn't getting pregnant and whether they should pursue medical services to help her conceive. Is she willing to undergo infertility testing and perhaps even pursue infertility services? To what extent is she willing to engage in an extended charade in order to conceal her medically induced sterilization?

Dr. Wilkins could support Mrs. Mason's wish not to become pregnant by suggesting effective alternatives to sterilization. Her husband might be agreeable to using of contraceptives, even a long-term contraceptive, since this would not permanently foreclose the possibility of another child. Dr. Wilkins could reflect on experiences with other pregnant women who had decided this was to be the last child but who changed their minds later. He could also encourage Mrs. Mason and her husband to seek out a counselor to help them work through their disagreement. Since their numerous one-to-one conversations on the topic "went nowhere," perhaps they need the assistance of a skilled counselor.

If it were clear that Dr. Wilkins was faced with the choice of either breaking confidentiality or outright lying (for example, if Mrs. Mason insisted that he record a false code on the insurance claim because her husband might see it), Dr. Wilkins would be justified in refusing to perform the procedure under those conditions. Otherwise, he should go ahead with the sterilization he previously agreed to perform but should carefully prepare his responses to Mr. Mason's anticipated questions. In addition, he should inform Mrs. Mason what those responses would be.

It is possible for Dr. Wilkins to respond in a way that protects patient confidentiality but is not deceptive. A possible scenario:

Mr. Mason: Did everything go OK?

Dr. Wilkins: Yes, fine. Mom and baby are doing great.

Mr. Mason: Is everything all right for Carol to have more babies?

Dr. Wilkins: She's in excellent health. But with the new federal laws on privacy, I need to be sure I have Carol's consent before I discuss specific medical information with anyone. As her husband, you're certainly in a special position here. I'd suggest that you discuss with her whether the two of you might want to make an appointment to come to my office together in the next few weeks.

When Mrs. Mason realizes that it is she, not Dr. Wilkins, who will have to answer her husband's questions, she may decide to pursue a different plan. It is she, not Dr. Wilkins, who will have to live with the consequences of her decision for her marriage and her family. The responsibility for these consequences rests on her, not on Dr. Wilkins.

Carol Tauer, PhD, is a bioethicist, Professor Emeritus at the College of St Catherine in St Paul, currently Visiting Faculty at the Center for Bioethics of the University of Minnesota, and a member of the Committee on Ethics of the American College of Obstetricians and Gynecologists.

\section{Commentary 2}

by Cynthia R. Daniels, PhD

Mrs. Mason's physician is correct to maintain patient-doctor confidentiality-it is indeed Mrs. Mason's body, and she has the right to make her own reproductive decisions. For instance, the courts have consistently struck down "husband notification" requirements in state abortion laws, and the same legal principle applies in this case. There is no legal obligation to inform the husband (or father, if the husband is not the biological parent).

Nevertheless, Mrs. Mason's request for a tubal ligation, without her husband's knowledge, is troubling and should send 
up red flags for the physician. Dr. Wilkins would be wise to further explore the reasons for the requested deception. Are there any outward signs that Mrs. Mason's husband is physically abusive? Is Mrs. Mason in danger of triggering a round of abuse if she reveals her planned action to her husband? Husbands who are abusive often try to isolate their partners. Mr. Mason's preference that his wife have more children rather than pursue her career may be indicative of this pattern. She is also asking Dr. Wilkins to act as a "barrier" between herself and her husband-another sign that there is fear in her relationship. Dr. Wilkins should be prepared to refer Mrs. Mason to domestic violence service if this is the case. If it is an abusive relationship that Mrs. Mason decides to end, she may have sacrificed her ability to have children with a different future partner—a decision she may later regret.

If this is not an abusive relationship, it is a troubled one. Mrs. Mason's actions are morally questionable. If indeed her husband is a caring father and partner, she may be seriously restricting her husband's future reproductive options by taking this action without his knowledge. Dr. Wilkins is right to encourage Mrs. Mason to be truthful and open. Her husband will no doubt learn of both the tubal ligation, as well as the deception, sooner or later. If she has postoperative complications and her husband is responsible for her care, he will learn of it sooner. Mrs. Mason may then well end up divorced and a single mother, or worse, in a contested divorce where her actions may be used against her in a custody battle. The physician has a responsibility to forewarn her not only of the medical but of the social consequences of her deception.

If confronted in the operating room, or elsewhere, by Mr. Mason about the possibility of future children, Dr. Wilkins should encourage Mr. Mason to treasure the two children his wife has already given him and, together with his wife, discuss their reproductive future.

Cynthia R. Daniels, PhD, is a professor in the Political Science Department at Rutgers University.

The people and events in this case are fictional. Resemblance to real events or to names of people, living or dead, is entirely coincidental. The viewpoints expressed on this site are those of the authors and do not necessarily reflect the views and policies of the AMA.

(C) 2003 American Medical Association. All Rights Reserved. 